\title{
Impact of climate change on major fruits in India
}

\section{NETHRAVATHI ASHOK PATIL, R.A. YELDHALLI, BHEEMANGOUDA O. PATIL AND LAXMI N. TIRLAPUR}

\author{
Article Chronicle : \\ Received: \\ 17.03.2015; \\ Revised : \\ 03.04.2015; \\ Accepted : \\ 26.04.2015
}

Key Words : Forecast, Climate, Markov chain
ABSTRACT : Horticulture sector contributes about 24.5 per cent of the GDP from about 8 per cent of the area under Horticulture. A large variety of fruits are grown in India. India accounts for 10 per cent of the total world production of fruits. India accounts for an area of 3.73 million ha under fruit crops with a production of 44.04 million tonnes. This study is conducted to asses Growth, variability in weather parameter, correlation in area, production and productivity of fruit crops, Shift in area among fruit crops and to forecast area under these fruits. The study is conducted based on secondary data taken from Metrological Department, NHB. To asses data various sophisticated tools was used using markov chain analysis, CGR, Correlation etc. The study reveals that CGR was significant in case of productivity of banana $(1.7 \%)$ and mango $(2.35 \%)$ at 1 per cent. CV was more in production of papaya with 35.04 per cent. There was negatively correlated in case of rainfall and minimum temperature with area production and productivity but in case of maximum rainfall it shows positively correlated, papaya production with 52 per cent. Highest area is retained by mango $(80.31 \%)$ followed by banana $(49.89 \%)$, citrus $(39.34 \%)$ and it has been forecast that area under all fruit crops increases.

How to Cite this ARTICLE : Patil, Nethravathi Ashok, Yeldhalli, R.A., Patil, Bheemangouda O. and Tirlapur, Laxmi N. (2015). Impact of climate change on major fruits in India. Asian J. Environ. Sci., 10(1): 34-38.

\section{Author for correspondence :}

\section{NETHRAVATHI}

\section{ASHOK PATIL}

Department of AgriBusiness Management, College of Agricultre, University of Agricultural Sciences, DHARWAD (KARNATAKA) INDIA Email: pnethra5@gmail. com

See end of the article for Coopted authors' 